\title{
Nutrition, Neuroinflammation and Cognition
}

\author{
Neha Vaidya and Subhadra Mandalika*
}

\author{
Department of Foods, Nutrition and Dietetics, College of Homescience, Nirmala Niketan, 49 New Marine \\ Lines, Mumbai, India
}

\begin{abstract}
Activation of microglia and astrocytes leads to the production of cytokines and other inflammatory mediators which may contribute to the apoptotic cell death of neurons observed in many neurodegenerative diseases such as Alzheimer's and Parkinson's disease. Vulnerability of the central nervous system (CNS) to oxidative and inflammatory stress increases with age and has been postulated to be a leading contributing factor to the cognitive impairment and thereby development of neurodegenerative diseases. Suppression of microglial production of neurotoxic mediators may result in neuroprotection. This heightens the interest in the development of neuroinflammation-targeted therapeutics. Nutrition is involved in the pathogenesis of age-related cognitive decline and also neurodegenerative diseases. Certain nutrients facilitate human brain function with their immediate and long term effects. On the other hand, malnutrition influences the brain throughout life, with profound implications on cognitive decline and dementia. Several phytochemicals with potent antioxidant and anti-inflammatory activities, have been shown to repress microglial activation and exert neuroprotective effects. Thus this review highlights the role of foods, nutrients and phytochemicals in suppressing neuro-inflammation and also enhancing cognition.
\end{abstract}

Keywords: Microglia, Neuroinflammation, Neurodegenerative diseases, Malnutrition, Antioxidant, Nutrients, Phytochemicals.

\section{INTRODUCTION}

Neurodegenerative diseases such as Alzheimer's disease (AD), Parkinson's disease (PD), Huntingtons's disease (HD), amyotrophic lateral sclerosis (ALS) are characterized by the chronic and progressive loss of neuronal functions, which in turn results in memory deficit, cognitive impairment and impaired neuromuscular coordination. According to the Global Burden of Disease estimates for the 2003 World Health Report, dementia contributed to $11.2 \%$ of years lived with disability in people aged 60 years and older which was more than the contribution of stroke $(9.5 \%)$, musculoskeletal disorders $(8.9 \%)$, cardiovascular disease $(5 \cdot 0 \%)$, and all forms of cancer $(2 \cdot 4 \%)$. Similarly, the disability weight for dementia, estimated by an international and multidisciplinary expert consensus, was higher than for almost any other health condition, apart from spinal-cord injury and terminal cancer [1]. It was estimated that 24.3 million people worldwide had dementia in 2005 which has increased to 35.6 million in 2010 , with numbers expected to almost double every 20 years to 65.7 million in 2030 and 115.4 million in 2050. Even in countries with low and/or middle income $58 \%$ of people lived with dementia in 2010 , with this proportion anticipated to rise to $63 \%$ in 2030 and $71 \%$ in 2050 [2].

The resident immune effector cells of central nervous system (CNS) i.e. microglia play a major role

*Address correspondence to this author at the Department of Foods, Nutrition and Dietetics, College of Home Science, Nirmala Niketan, 49 New Marine Lines, Mumbai, India; Tel: 9920098880; E-mail: drmsubhadra@gmail.com in managing the brain homeostasis. They are the first responders against infectious, inflammatory and pathophysiological stimuli and react to these conditions by modulating their motility, phagocytic functions, shape of processes, and release of cytokines, chemokines, reactive oxygen species, prostaglandin metabolites and expression of innate and adaptive immune-function molecules [3, 4]. However, excessive production these substances may lead to neuroinflammation and neurodegeneration where as reduced production offers neuroprotection. Realisation of the importance of neuroprotection lead to the testing of plant products and their active components; screening of various pharmaceutical agents and development of novel synthetic compounds that selectively down regulate neuro inflammatory responses and finally resulted in the rapid discovery of neuroinflammation-targeted therapeutics [5].

Aging increases the vulnerability of the central nervous system (CNS) to oxidative and inflammatory stress. This is a leading contributing factor to the alarming rise in the incidence of Parkinson's and Alzheimer's diseases. Optimal brain function results from highly complex interactions between numerous genetic and environmental factors such as food intake, physical activity, age and stress [6]. Macronutrients especially essential fatty acids (EFA) and certain amino acids (e.g. choline, methionine) and micronutrients that are involved in DNA methylation (e.g. folate, vitamins $B_{6}$ and $B_{12}$ etc.,) have both immediate and long-term effects on the epigenome influencing gene expression in the neurons of CNS. Moreover, energy contribution 
from each of the macronutrients was also found to influence neuronal functioning and thereby cognitive performance. Malnutrition is involved in the pathogenesis of age-related cognitive decline and neurodegenerative diseases. Plant foods consumed as part of a normal diet not only provide nutrients and energy, but also offer health benefits beyond basic nutritional functions [7].

Several nutritional intervention trials have been conducted towards prevention and treatment of neuroinflammation. A study conducted by Yuliva et al, in 2004 [8] showed that an experimental diet composed of eicosapentaenoic acid (EPA, 20:5, n-3), docosahexaenoic acid (DHA, 22:6, n-3), zinc, curcumin, piperine, melatonin, choline and uridine attenuated cognitive and behavioral deficits, reduced hippocampal atrophy and peripheral immune activation in mouse model thus proving its therapeutic benefit in the prevention and treatment of neurodegenerative diseases. In another study, different food samples like lime zest, English breakfast tea, honey-brown mushroom, button mushroom, oyster mushroom, cinnamon and cloves inhibited NO production in N11 microglia [9].

\section{DISCUSSION}

Dietary factors can affect multiple brain processes by regulating neurotransmitter pathways, synaptic transmission, membrane fluidity and signaltransduction pathways. A review conducted by Gomezpinilla (2008) stated that dietary components can influence epigenetic events such as DNA methylation, transcriptional activation, translational control and posttranslational modifications that cause a potentially heritable phenotypic change and have potential for disease modulation. Thus the effects of diet on mental health can be transmitted across generations [10]. It is interesting to note that food components including nutrients and phytochemicals, whole foods as well as food combinations were found to exhibit neuro protective effects. The individual impact of each of these on neuroinflammation has been discussed below. Studies on the association between nutrients and cognitive functioning have examined both supplemental and dietary intake with dietary sources generally exhibiting stronger effects.

\section{Role of Dietary Energy and Macronutrients in Cognition}

Caloric content of the diet has shown to affect cognition as the metabolic processes that are initiated by the burning of fuels in mitochondria can modulate synaptic plasticity [10]. Moreover, individual macronutrients consumed within a meal differentially affect cognitive performance [11, 12]. Dietary pattern including high carbohydrate, low protein and low fat has been found to increase the risk of $\mathrm{MCl}$ or dementia in geriatric subjects [13]. Kaplan et al, in 2001 [11] examined the impact of macronutrients on cognition and reported that pure dietary protein, carbohydrate, and fat individually enhanced memory performance. Diets containing low carbohydrate and low fat have also shown to improve the cognitive abilities and enhance mood in overweight and obese participants [14].

\section{Carbohydrates}

Glucose provides energy to the brain and is essential component for brain metabolism. Regulation of glycaemia improves the quality and duration of intellectual performance. Poor glycaemic control is associated with lower performances on tests of memory in all age groups of non diabetic as well as diabetic individuals. Scientific data demonstrated clear associations between elevated glycaemia which may be partly due to the effect of dietary and lifestyle factors; and relatively poor cognitive performance. Dietary fibre content in foods influences the speed at which the foods increase blood glucose level. Overall, presence of dietary fibre in the diet was shown to be associated with higher alertness ratings and ensures less perceived stress [15, 16]. Glycemic index and glycemic load are the concepts often used to understand the contribution of foods to blood glucose level. Gilsenan et al (2009) opined that there is insufficient evidence to demonstrate a consistent directional effect of Glycemic Load on short-term cognitive performance [17]. But in a recent review, in spite of inconsistent results of various studies, it was concluded that a low Glycaemic index meal may favour cognition [18]. Future studies employing consistent methodologies to facilitate meaningful comparisons and interpretation of results would help to further establish the role of complex carbohydrates in cognition.

Very low carbohydrate consumption has been reported to provide neurocognitive benefit to older adults suffering from early memory decline, increased risk for neuro-degeneration and thereby increased risk of Alzheimer's disease. The mode of action was attributed to the dietary ketosis induced by carbohydrate restriction [19]. 
The effect of glucose and saccharin drink on cognition was compared in a review which included only one randomised control trial. Results showed a better cognitive performance among the participants on consumption of glucose drink than saccharin drink. However, since only one RCT was included, strong recommendation on the use of any particular form of carbohydrate for enhancing cognitive performance in older adults could not be made. Contradictorily, significant beneficial effects of oligosaccharide supplementation were found on memory performance and indicators of well-being [20]. However, more studies on various forms of carbohydrates are needed to find out complex nutritional interactions [20].

\section{Proteins}

The nature and the quantities of cerebral proteins and neurotransmitters are influenced by the quality of dietary proteins. Amino acids like tryptophan, glutamine, glutathione and taurine contribute to cerebral function. Thus, the amino acid profile of the cerebral extracellular milieu is a function of the content and nature of dietary proteins. In fact, some indispensable amino acids present in dietary proteins help in the regulation of neurotransmitters and neuromodulators. Kwashiorkor which implies protein deficiency can severely affect the functioning of the brain [15].

Some genetic disorders cause alterations in the brain, due to abnormal changes in metabolism such as phenylketonuria, caused by abnormal metabolism of an essential amino acid, tryptophan. Hulsken et al., (2013) in their review examined the effect of tryptophan intake on cognition and reported that intake of foods containing moderate to high tryptophan like chicken, soyabeans, cereals, tuna, nuts and bananas help in improving cognitive abilities, whereas higher intake of those foods containing very low tryptophan like cereals, maize and milk formulas may lead to cognitive impairment. However enhancing available tryptophan in these foods may represent an efficient and costeffective way of increasing mood and cognition [21].

\section{Fat}

Different types of fatty acids influence cognition differently. Fatty acids like PUFA and MUFA may have a beneficial role whereas SFA may lead to neuroinflammation and thus impair cognition. Moreover, the source of fatty acids also plays an important role in cognition. A study conducted on adults
(39 to 65 years) concluded that consumption of low fat dairy products have beneficial effects on social functioning, stress and memory, while intake of whole fat dairy products, rich source of SFA may be associated with poorer psychological well-being. More dietary intervention trials are needed in order to understand the relationship if any between dairy consumption and cognitive and psychological health [22].

Essential polyunsaturated fatty acids (PUFA) are important class of nutritional lipids that are not synthesized in the body and thus must be obtained from the diet. They, especially the Omega-3 type polyunsaturated fatty acids play important roles in cell integrity, maintenance and development; and are key components of glial cell biomembranes. PUFAs deposit in the brain during the perinatal period depending on the dietary supply. They regulate both prostaglandin and pro-inflammatory cytokine production in the immune system and thus exhibit immunomodulatory properties. Omega 3 fatty acids are highly antiinflammatory, while n-6 fatty acids are proinflammatory. The protective role of $n-3$ fatty acids in neurodegenerative diseases is often linked to aging [23] as the brain levels of PUFAs diminish with age. Moreover, the increasing exposure of the population to diets low in PUFAs may lead to increased production of inflammatory cytokines in the brain.

Consuming monounsaturated fatty acids and PUFAs have shown to slow cognitive decline in animals and in humans. Most studies have emphasized beneficial role of PUFAs found in fish and nuts on cognitive abilities in aged animals. Numerous studies have also shown that consuming diets deficient in $\omega 3$ fatty acids will impair cognitive functioning [24]. But the role of PUFAs needs to be better characterized by multidisciplinary studies aimed at assessing the effects of these molecules at different levels, from the molecular level to that of the organism as a whole [25].

Among the PUFAs, DHA has been studied more extensively with regard to its role in neuroinflammation. DHA (docosahexaenoic acid) is one of the important constituents of membrane phospholipids of brain and thus necessary for normal neuronal function. High amounts of DHA are found in the nervous system, particularly in photoreceptors and synaptic membranes. DHA has been shown to reduce expression of tumor necrosis factor-a, interleukin-6, nitric oxide synthase, and cyclo-oxygenase- 2 , induced by interferon-g, and induced up regulation of heme oxygenase-1 (HO-1) in 
BV-2 microglia. DHA has also been reported to reduce the amyloid production, accumulation, and downstream toxicity in aged Alzheimer mouse model. Therefore it can be used as a potential therapeutic agent in the treatment of Alzheimer's disease [26].

DHA administered for 12 weeks significantly improved the working memory errors and also enhanced the spatial cognition and learning ability [27]. Furthermore, DHA suppressed the high levels of lipid peroxide and reactive oxygen species in the cerebral cortex and the hippocampus of $A \beta$-infused rats, suggesting that DHA increases anti-oxidative capacities. Therefore it can be concluded that DHA may act as a therapeutic agent for improving learning deficits in Alzheimer's disease [28]. Moreover, studies have also shown that dietary DHA supplementation enhances the supportive action of exercise on learning and memory capacity and synaptic plasticity $[29,30]$.

A transgenic model expressing an $n-3$ fatty acid desaturase which converts n-6 PUFAs into n-3 PUFAs was studied. Results confirmed the capacity of the transgene to produce n-3 PUFAs, thereby increasing the brain $n-3: n-6$ PUFA ratio. This helped in reducing the inflammatory processes in the brain although it was not as effective as dietary DHA supplementation. Overall, the results strongly suggested that dietary intervention with $\mathrm{n}-3$ fatty acids particularly DHA constitutes a potent method to achieve neuro protective levels in the brain, particularly in the context of Parkinson's disease [31]. Another study conducted by Delpech et al, (2015) confirmed the above findings [32]. The results of their study not only provided insight into how n-3 PUFAs can influence microglia activity but also suggested a role for EPA and DPA in the prevention of spatial memory deficit linked to inflammation. Central n3 PUFA increase observed in transgenic mice modulated the brain innate immune system activity, leading to the protection of animals against LPSinduced pro-inflammatory cytokine production and subsequent spatial memory alteration [32].

In addition to DHA, the monounsaturated fatty acid (MUFA) oleic acid was found to inhibit LPS-induced phosphorylation of Akt and p38 MAPK in an in vitro study. It was also seen that oleic acid suppressed the release of proinflammatory mediators NO and PGE2 as well as the expression of i-NOS and COX-2 in LPSstimulated microglia. This anti-inflammatory effect of oleic acid is associated with blockade of ROS accumulation, $\mathrm{p} 38$, and Akt/IKK/NF-kB signaling pathways in LPS-stimulated BV2 microglia. This finding suggests that oleic acid may provide a beneficial effect on the treatment of inflammatory brain damage induced by microglial activation, although further studies on animal model are necessary to know whether oleic acid shows similar anti-inflammatory effect in vivo too [33].

Long-term consumption of both refined and pomace olive oil changed the brain fatty acid composition in a mice model and exhibited positive effects on neuroinflammation and brain function. The effect has been attributed to the presence of oleic acid in these oils [34]. Thus these oils can be regarded as functional foods in neurodegenerative diseases. Older adults with moderate or intensive use of olive oil showed lesser cognitive deficit as compared to those who did not use olive oil, however the association needs to be confirmed further [35]. In order to establish a direct therapeutic benefit of oleic acid in neurodegeneration, it is necessary to conduct experimental research on persons suffering from neurodegenerative diseases.

Short chain fatty acids (SCFA) were also found to decrease the production of inflammatory molecules. For example, butyrate has decreased the production of pro-inflammatory mediators including TNF- $\alpha, \mathrm{NO}$ and IL-6 in glial cells. It also improved the release of the anti-inflammatory cytokine IL-10 and inhibited the microglial activation in the ischemic brain of rats. Thus due to its potential to decrease neuroinflammation, butyrate could be regarded as neuroprotective fatty acid $[36,37]$.

\section{Role Micronutrients in Cognition}

The water-soluble vitamins ( $B$ group and $C$ ), and minerals like calcium, magnesium and zinc are associated with cognitive performance. Marginal deficiencies of these micronutrients may negatively influence cognitive performance, especially in elderly and those adults who are exposed to occupational pressures along with a stressful lifestyle [38].

Vitamin B 12 deficiency has been associated with cognitive impairment. Its been postulated that low vitamin $B_{12}$ status may lead to neurotoxicity and deficiency of S-adenosylmethionine (SAM), and thus result in deficient methylation reactions in the central nervous system. Low levels of SAM have been found in the brain and cerebrospinal fluid of patients suffering from Alzheimer's disease [39]. Surprisingly, high folate intake was associated with cognitive decline in a population based study on older adults, though high intake of folate may cover up vitamin $B_{12}$ deficiency 
with regard to haematological symptoms, but the neurological symptoms and neuropsychiatric changes would continue. The possible mechanism might be that both the vitamins perform similar function i.e. synthesis of Sadenosyl-methionine (SAM), which is the most important methyl-group donor of the brain [41]. In another study on older adults, it was seen that high homocysteine levels increased the risk of dementia. However the association between total homocysteine and dementia is independent of plasma folate, $\mathrm{B}_{12}$ and antioxidant micronutrient status [40,42].

Harrison (2012) reviewed several studies on Vitamin $\mathrm{C}$ and concluded that it can be protective against the oxidative damage that is involved in the pathology of Alzheimer's disease as well as cognitive decline associated with aging [43].

Vitamin E bioavailability, metabolism and plasma levels have been studied in humans and in $A D$, particularly as $\alpha$-tocopherol. Alpha tocopherol is widely tested in randomized controlled trials in subjects with $\mathrm{AD}$ and $\mathrm{MCl}$. Vitamin $\mathrm{E}$ can cross the blood brain barrier and lower lipid peroxidation and $\beta$-amyloid deposition. It also prevents neuronal damage in the brain by decreasing isoprostane levels [44]. Vitamin D deficiency in the body is linked to poor cognitive performance and increased risk of $A D$, however the mechanism is unclear and therefore further studies are required $[45,46]$.

In a meta-analysis, it was concluded that iron supplementation improved attention and concentration in adolescents and adult women irrespective of baseline level of iron status. Iron supplementation also improved IQ in women and children who were anaemic at baseline, but had no effect in other groups or on other cognitive domains [47]. However, results of a study conducted by McNeill et al, (2007) showed that daily consumption of multivitamin and multimineral supplements may not improve different domains of cognitive function in geriatric population [48].

\section{Role of Phytochemicals in Cognition}

Polyphenols help in reduction of neuroinflammation via attenuation of the release of cytokines, such as interleukin-1betan (IL-1 $\beta$ ) and tumor necrosis factoralpha (TNF- $\alpha$ ) and down regulation of the proinflammatory transcription factors such as Nuclear Factor (NF-KB) [49]. Natural polyphenols inhibit glutamate-induced activation of calpains, normalize the levels of phosphorylated Akt kinase and cytosolic Bax, and regulate the nuclear translocation of NF-KB. Each of these effects contributes to the substantial reduction of apoptotic neuronal death induced by glutamate. Thus it seems that polyphenolic compounds may inhibit NF-KB activity leading to downregulation of iNOS gene transcription. These mechanisms together with NADPH oxidase inhibition finally result in significant reduction of neuronal death [50].

Several phytochemicals in foods with potent antioxidant and anti-inflammatory activities, such as resveratrol and curcumin, have been shown to repress microglial activation and exert neuroprotective effects in the central neuron system following injury $[19,51]$. The anti-neuroinflammatory and anti-cognitive impairment effects of several phytochemicals are consolidated and tabulated in Table 1.

In a review studying association between polyphenols and cognition, it was concluded that consuming additional polyphenols in the diet certainly led to cognitive benefits, but the observed effects were small. Polyphenol consumption influenced declarative memory, particularly spatial memory with the effects depending on the source of polyphenol. Berry fruit juice consumption improved immediate verbal memory, whereas isoflavone based interventions led to significant improvements in delayed spatial memory and executive function. However, the methodological inconsistencies hampered comparison between studies. Thus there was lack of clear evidence for an association between cognitive performance and polyphenol dose response and duration of intervention. In conclusion, the findings do imply that polyphenol consumption has potential benefits on cognition both acutely and chronically [52].

Blueberry supplementation has been shown to effectively decrease the proinflammatory mediators both in vitro and in vivo experiments [53, 54]. Crude extract of blueberry decreased the production of inflammatory molecules in lipopolysaccharide (LPS) activated murine BV2 microglia [55] and the effect was attributed to the presence of polyphenols. Thus it was concluded that diet rich in polyphenols can alleviate the inflammation associated with neurodegenerative diseases [56].

Dietary supplementation with fruit or vegetable extracts high in antioxidants (e.g. blueberries, strawberries, walnuts, and Concord grape juice) has shown to improve behaviour and decrease the 
Table 1: Anti-Neuroinflammatory and Anti-Cognitive Impairment Effects of Phytochemicals

\begin{tabular}{|c|c|c|c|c|c|}
\hline Sr. No & Phytochemical & Food sources & Experimental model & Effect & Reference \\
\hline 1. & Ferulic acid & $\begin{array}{l}\text { Vegetables and } \\
\text { maize bran }\end{array}$ & Mouse & $\begin{array}{c}\text { Reversed the } \\
\text { neuroinflammation and } \\
\text { ameliorated memory loss }\end{array}$ & [70] \\
\hline 2. & $\begin{array}{l}\text { Curcumin and } \\
\text { Tetrahydrocircumin, } \\
\text { Aromatic (ar)-turmerone }\end{array}$ & Turmeric & Mouse & $\begin{array}{c}\downarrow \text { production of TNF- } \alpha, \text { IL-1 } \\
\text { IL- } 6 \text {, and MCP-1, } \\
\text { ROSInhibition of NF-kB, JNK, } \\
\text { and p38 MAPK signaling } \\
\text { pathways } \downarrow \text { Transcription } \\
\text { factors or co-activators of } \\
\text { activator protein- } 1\end{array}$ & {$[71,72]$} \\
\hline 3. & Cinnamaldehyde & Cinnamon & $\begin{array}{l}\text { LPS activated BV2 } \\
\text { microglia }\end{array}$ & $\begin{array}{l}\downarrow \text { production of nitric oxide } \\
\text { (NO), IL-1 } \beta, \text { IL- } 6 \text {, and TNF- } \alpha \text {; } \\
\text { attenuation of NF-kB activation }\end{array}$ & {$[73]$} \\
\hline 4. & Hydroxytyrosol & Olives & $\begin{array}{l}\text { LPS activated BV2 } \\
\text { microglia }\end{array}$ & $\begin{array}{c}\downarrow \text { production of pro- } \\
\text { inflammatory cytokines and } \\
\text { oxidative molecules }\end{array}$ & {$[74,75]$} \\
\hline 5. & $\begin{array}{l}\text { Sesame lignans such as } \\
\text { sesamin, episesamin, sesamol, } \\
\text { sesamolin, and g-tocopherol }\end{array}$ & Sesame seeds & $\begin{array}{l}\text { LPS activated BV2 } \\
\text { microglia }\end{array}$ & $\begin{array}{l}\downarrow \text { NO production, iNOS mRNA } \\
\text { and protein expression and } \\
\text { other inflammatory molecules }\end{array}$ & {$[76]$} \\
\hline 6. & $\begin{array}{l}\text { 6-Shogaol, 6-Gingerol, 10- } \\
\text { Gingerol }\end{array}$ & Ginger & Mouse & $\begin{array}{c}\downarrow \text { production of nitric oxide, IL- } \\
1 \beta, I L-6 \text { and TNF- } \alpha \text { as well as } \\
\text { their mRNA levels, attenuation } \\
\text { of NF-KB activation }\end{array}$ & {$[77]$} \\
\hline 7. & Chrysin and propolis & $\begin{array}{c}\text { Honey, fruits, } \\
\text { vegetables, and } \\
\text { certain beverages }\end{array}$ & $\begin{array}{l}\text { LPS activated BV2 } \\
\text { microglia }\end{array}$ & $\begin{array}{c}\downarrow \text { Production of NO, TNF- } \alpha, \text { IL- } \\
1 \beta, \text { i-NOS and COX-2 and } \\
\text { attenuation of JNK and NF-KB }\end{array}$ & [78] \\
\hline 8. & Luteolin & $\begin{array}{l}\text { Celery and green } \\
\text { peppers }\end{array}$ & Mouse, Microglia & $\begin{array}{c}\downarrow \text { production of IL-1 } 1 \beta, \mathrm{IL}-6, \\
\text { TNFa, NO, and prostaglandin } \\
\text { E2, i-NOS, COX-2, PGE2, NO, } \\
\text { NF-KB }\end{array}$ & {$[59,79,80]$} \\
\hline 9. & Resveratrol & $\begin{array}{l}\text { Grapes, } \\
\text { blueberries, } \\
\text { raspberries, and } \\
\text { mulberries }\end{array}$ & $\begin{array}{l}\text { LPS stimulated BV2 } \\
\text { microglia } \\
\text { Mouse }\end{array}$ & $\begin{array}{c}\downarrow \text { Production of } \mathrm{IL}-1 \mathrm{~b} \\
\text { Attenuating acute cognitive } \\
\text { disorders }\end{array}$ & {$[81,82]$} \\
\hline 10. & Quercetin & $\begin{array}{l}\text { Fruits and } \\
\text { Vegetables }\end{array}$ & $\begin{array}{c}\text { LPS stimulated BV2 } \\
\text { microglia }\end{array}$ & $\begin{array}{l}\downarrow \text { Production of TNF-a, IL- } 1 \mathrm{~b}, \\
\text { IL-6, i-NOS and mitochondrial } \\
\text { superoxide radicals }\end{array}$ & [82] \\
\hline 11. & Isoflavones (Diadzein) & $\begin{array}{l}\text { Soyabean, } \\
\text { Tempeh }\end{array}$ & Mouse & $\begin{array}{c}\downarrow \text { Production of IL-6, NO, ROS. } \\
\text { Attenuation of p38 MAPK } \\
\text { phosphorylation, and NF-kB } \\
\text { activation }\end{array}$ & {$[83,84]$} \\
\hline 12. & Catechins & Green tea & Rat & $\begin{array}{c}\text { Improve the spatial cognition } \\
\text { learning abilities, } \uparrow \text { antioxidant } \\
\text { activity }\end{array}$ & {$[85]$} \\
\hline 13. & Theaflavins & Black tea & - & $\downarrow$ Neurotoxicity & [86] \\
\hline
\end{tabular}

oxidative stress caused due to aging. The beneficial effects of fruits and vegetable consumption also included enhancement of neuronal communication due to increased neuronal signalling and decreased stress signals that were induced by oxidative/inflammatory stressors (e.g. nuclear factor -kB) [57].

Berry fruit supplementation has also been effective in reversing age related cognitive decline in animal studies. The antioxidant-rich berries consumed in the diet can positively influence learning and memory in the aged mice. This effect is thought to be due to the direct relationship of berry polyphenols with neurons and thus reducing the impact of stress-related cellular signals and increasing the capacity of neurons to maintain proper functioning during aging [58].

Several studies have demonstrated that flavonoids significantly inhibited the activation of NF-KB and MAPK pathways in activated microglia and thus 
attenuated the production of inflammatory molecules [59]. Foods rich in three specific flavonoid sub-groups, the flavanols, flavanones and anthocyanins possess the greatest potential to act on the cognitive processes. Age-dependent deterioration in memory and cognition can be reversed by the consumption of flavonoid-rich berries, apples and citrus fruits throughout life. They also protect vulnerable neurons and influence the cognitive performance [60]. The effects of flavonoidrich foods on improvement of age-related cognitive and motor decline have been shown with blueberries, concord grapes, strawberries, and polyphenols from red wine [61].

The flavanols, catechin and epigallocatechin gallate (EGCG), are able to attenuate microglia and/or astrocyte mediated inflammation These include iNOS and cyclooxygenase (COX-2) expression, cytokine release, NO production and NADPH oxidase activation. All these effects are linked to the ability to modulate directly various protein and lipid kinase signalling pathways. These include, for example, the inhibition of tyrosine kinase, protein kinase $\mathrm{C}$ and mitogen activated protein kinase (MAPK) signaling cascades. The latter cascades involve p38 or ERK1/2 which regulate both iNOS and the expression of the cytokine tumour necrosis factor-alpha (TNF-a) in activated glial cells $[62,63,64]$.

In a population-based study, it was concluded that intake of flavonoid-rich food, including chocolate, wine, and tea, is associated with better performance across several cognitive abilities and that the associations are dose dependent. However, the mechanisms were unknown and therefore further studies are required [65].

A study showed that Hesperidin, nobiletin, and tangeretin individually were not effective for reducing neuroinflammation, however in combination, they significantly reduced LPS-induced proinflammatory cytokine expression. Overall, tangerine peel possesses potent anti-neuroinflammatory capacity, which was attributed to the collective effect of hesperidin, nobiletin, and tangeretin [66]. The flavanones naringenin and hesperetin and the flavanols catechin and epicatechin, also inhibited LPS induced TNF- $\alpha$ production and attenuated ERK, JNK, MAPKs, NF-KB activation in LPS stimulated BV2 microglia. Apart from these, naringenin also inhibited LPS induced iNOS expression and nitric oxide production in glial cells [67, 68].

Table 2: Anti-Neuroinflammatory and Anti-Cognitive Impairment Effects of Whole Foods and Food Products

\begin{tabular}{|c|c|c|c|c|c|}
\hline Sr. No. & Food & $\begin{array}{l}\text { Bioactive } \\
\text { Component }\end{array}$ & $\begin{array}{l}\text { Experimental } \\
\text { model }\end{array}$ & Effect & Reference \\
\hline 1. & Spinach & - & Rats & $\begin{array}{l}\uparrow \text { production of TNF } \alpha \text { and IL- } 1 \beta \text { in the } \\
\text { cerebellum of old rats was reversed by intake of } \\
\text { spinach rich diet for } 6 \text { weeks }\end{array}$ & [87] \\
\hline 2. & Bitter melon & Extract & Microglial cells & $\begin{array}{l}\downarrow \text { high fat diet associated neuroinflammation } \\
\text { And } \downarrow \text { oxidative stress }\end{array}$ & [88] \\
\hline 3. & Mulberry leaves & & Animal model & $\begin{array}{c}\downarrow \text { microgliosis and astrogliosis, } \downarrow \text { release of nitric } \\
\text { oxide from microglia and cytokine release from } \\
\text { activated astrocytes }\end{array}$ & [89] \\
\hline 4. & Cinnamon & sodium benzoate & $\begin{array}{l}\text { mouse microglia } \\
\text { and astrocytes }\end{array}$ & $\begin{array}{l}\downarrow \text { Production of iNOS, TNF- } \alpha \text { and IL-1 } \beta \text { and } \\
\text { surface markers (CD11b, CD11c, and CD68) }\end{array}$ & [90] \\
\hline 5. & Spirulina & - & $\begin{array}{l}\text { Microglial cells } \\
\text { (BV2 cell line) }\end{array}$ & $\downarrow$ Production of iNOS, COX-2, TNF- $\alpha$, and IL-6 & [91] \\
\hline 6. & English walnuts & & $\begin{array}{l}\text { Microglial cells } \\
\text { (BV2 cell line) }\end{array}$ & $\downarrow$ Production of TNFa and iNOS & [92] \\
\hline 7. & $\begin{array}{l}\text { Aged garlic } \\
\text { extract }\end{array}$ & & Rat model & $\begin{array}{c}\text { diminished the neurological alterations }(61.6 \%) \text {, } \\
\text { the infarct area }(54.8 \%) \text { and the histological } \\
\text { damage }(37.7 \%) \text { induced by cerebral ischemia, } \\
\downarrow \text { TNFa and COX-2 protein levels }\end{array}$ & [93] \\
\hline 8. & Broccoli & Sulforaphane & Mouse & $\begin{array}{c}\downarrow \text { age-elevated cytochromeb- } 245 \beta \text {, an oxidative } \\
\text { stressmarker, and } \downarrow \text { glial activation markers }\end{array}$ & [94] \\
\hline 9. & $\begin{array}{l}\text { Energy drinks } \\
\text { containing } \\
\text { caffeine, taurine } \\
\text { and glucose }\end{array}$ & & Humans & $\begin{array}{l}\text { Enhanced executive control and working } \\
\text { memory, and reduced simple and choice } \\
\text { reaction time, enhanced object working memory } \\
\text { and enhanced orienting attention. }\end{array}$ & [95] \\
\hline
\end{tabular}


Several other foods and food products like traditional herbs, certain fruits and vegetables, spices, nuts and nutraceutical products (energy drinks) have shown to be potent anti-neuroinflammatory agents and thus also help to improve cognitive abilities (Refer to Table 2). Ginseng extract and total saponins reduced LPS-induced expression of MMP-9, oxidative and proinflammatory cytokines in microglial cells. Similar effects were also observed in the mouse brain stimulated with LPS. Ginsenosides are easily absorbed into the body and thus they have been used to treat various diseases. The strong inhibition of microglial activation by ginsenosides may provide potential therapeutic strategies for neurodegenerative diseases such as Alzheimer's disease. Further research on the effects and molecular mechanisms of purified ginsenosides, is essential [69].

\section{CONCLUSION}

Thus, from the above discussion it is evident that neurodegeneration is yet another inflammatory disease affecting the cognitive performance and thereby the quality of life. The increasing incidence of the same is indeed a serious cause of global concern, necessitating identification and implementation of preventive and therapeutic measures.

Nutritional therapy of neurodegeneration includes a healing system consisting of the nutrients, bioactive chemicals present in functional foods and nutraceuticals. Regular dietary consumption of EFA, micronutrients and phytochemicals would help in preventing cognitive impairment and thereby protect population from neurodegenerative diseases as evident from extensive scientific research. Besides offering preventive benefits in cognitive impairment, good nutrition could also enhance cognitive performance.

\section{REFERENCES}

[1] Ferri CP, Prince M, Brayne C, Brodaty H, Fratiglioni L, Ganguli $M$, et al. Global prevalence of dementia: a Delphi consensus study Alzheimer's Disease International Lancet. 2005; 366 (9503): 2112-7. http://www.ncbi.nlm.nih.gov/ pubmed/16360788

[2] Lunn S, Sakowski S, Hur J, Feldman E. Stem Cell Technology for Neurodegenerative Diseases Ann Neurol 2011; 70(3): 353-361. doi: 10.1002/ana.22487. http://www.ncbi.nlm.nih.gov/pmc/articles/PMC3177143/

[3] Griffiths M, Neal JW, Gasque P. Innate immunity and protective neuroinflammation: new emphasis on the role of neuroimmune regulatory proteins Int Rev Neurobiol 2007; 82: 29-55.

http://dx.doi.org/10.1016/S0074-7742(07)82002-2

[4] Garden GA, Möller T. Microglia biology in health and disease. J Neuroimmune Pharmacol 2006; 1(2): 127-37. http://dx.doi.org/10.1007/s11481-006-9015-5
Choi DK, Koppula S, Suk K Inhibitors of microglial neurotoxicity: focus on natural products. Molecules 2011; 16(2): 1021-43. Published online 2013 Aug 14. http://dx.doi.org/10.3390/molecules16021021

[6] Dauncey MJ. Nutrition, the brain and cognitive decline: insights from epigenetics. Eur J Clin Nutr 2014; 68(11): 117985.

http://dx.doi.org/10.1038/ejcn.2014.173

[7] Iriti M, Vitalini S, Fico G, Faoro F. Neuroprotective herbs and foods from different traditional medicines and diets. Molecules 2010; 15(5): 3517-55.

http://dx.doi.org/10.3390/molecules15053517

[8] Borre YE, Panagaki T, Koelink PJ, Morgan ME, Hendriksen $\mathrm{H}$, Garssen J, et al. Neuroprotective and cognitive enhancing effects of a multi-targeted food intervention in an animal model of neurodegeneration and depression. Neuropharmacology 2014; 79: 738-49. http://dx.doi.org/10.1016/j.neuropharm.2013.11.009

[9] Gunawardena D, Shanmugam K, Low M, Bennett L, Govindaraghavan S, Head R, et al. Determination of antiinflammatory activities of standardised preparations of plantand mushroom-based foods. Eur J Nutr 2014; 53(1): 335-43. http://dx.doi.org/10.1007/s00394-013-0531-9

[10] Gomez-Pinilla F. Brain foods: the effects of nutrients on brain function. Nat Rev Neurosci 2008; 9(7): 568-578. http://dx.doi.org/10.1038/nrn2421

[11] Kaplan R, Greenwood C, Winocur G, Wolever T. Dietary protein, carbohydrate and fat enhance memory performance in the healthy elderly. Am J Clin Nutr 2001; 74: 687-693. http://ajcn.nutrition.org/content/74/5/687

[12] Fischer K, Colombani PC, Langhans W, Wenk C. Carbohydrate to protein ratio in food and cognitive performance in the morning. Physiold Behav 2002; 75: 411423.

http://dx.doi.org/10.1016/S0031-9384(01)00676-X

[13] Roberts RO, Roberts LA, Geda YE, Cha RH, Pankratz VS, O'Connor HM, et al. Relative intake of macronutrients impacts risk of mild cognitive impairment or dementia. $J$ Alzheimers Dis 2012; 32(2): 329-39. http://www.ncbi.nlm. nih.gov/pubmed/22810099

[14] Brinkworth GD, Buckley JD, Noakes M, Clifton PM, Wilson CJ. Long-term effects of a very low-carbohydrate diet and a low-fat diet on mood and cognitive function. Arch Intern Med 2009; 169(20): 1873-80.

http://dx.doi.org/10.1001/archinternmed.2009.329

[15] Bourre JM. Effects of nutrients (in food) on the structure and function of the nervous system: update on dietary requirements for brain. Part 2: macronutrients. J Nutr Health Aging 2006; 10(5): 386-99. http://www.ncbi.nlm.nih.gov/ pubmed/17066210

[16] Riby LM, McLaughlin J, Riby DM, Graham C. Lifestyle, glucose regulation and the cognitive effects of glucose load in middle-aged adults. Br J Nutr 2008; 100(5): 1128-34. http://dx.doi.org/10.1017/S0007114508971324

[17] Gilsenan MB, de Bruin EA, Dye L. The influence of carbohydrate on cognitive performance: a critical evaluation from the perspective of glycaemic load. $\mathrm{Br} J$ Nutr 2009; 101(7): 941-9.

http://dx.doi.org/10.1017/S0007114508199019

[18] Philippou E, Constantinou M. The influence of glycemic index on cognitive functioning: a systematic review of the evidence. Adv Nutr 2014; 5(2): 119-30. http://dx.doi.org/10.3945/an.113.004960

[19] Krikorian R, Shidler MD, Dangelo K, Couch SC, Benoit SC Clegg DJ. Dietary ketosis enhances memory in mild cognitive impairment. Neurobiol Aging 2012; 33(2): 425.e19-27. http://dx.doi.org/10.1016/j.neurobiolaging.2010.10.006

[20] Ooi CP, Loke SC, Yassin Z, Hamid TA. Carbohydrates for improving the cognitive performance of independent-living 
older adults with normal cognition or mild cognitive impairment. Cochrane Database Syst Rev 2011; (4): CD007220.

http://dx.doi.org/10.1002/14651858.cd007220.pub2

[21] Hulsken S, Märtin A, Mohajeri MH, Homberg JR. Foodderived serotonergic modulators: effects on mood and cognition. Nutr Res Rev 2013; 26(2): 223-34. http://dx.doi.org/10.1017/S0954422413000164

[22] Crichton GE, Murphy KJ, Bryan J. Dairy intake and cognitive health in middle-aged. South Australians Asia Pac J Clin Nutr 2010; 19(2): 161-71. http://www.ncbi.nlm.nih.gov/pubmed/ 20460228

[23] Laye S, Dantzer D. Polyunsaturated Fatty Acids and NeuroInflammation Nutrient, stress and Medical Disorders Shlomo Yehuda, PhD David I. Mostofsky, PhD 2006.

[24] Willis LM, Shukitt-Hale B, Joseph JA. Modulation of cognition and behavior in aged animals: role for antioxidant- and essential fatty acid-rich plant foods. Am J Clin Nutr 2009; 89(5): 1602S-1606S.

http://dx.doi.org/10.3945/ajcn.2009.26736J

[25] Laye S, Delpech JC, Smedt-Peyrusse VD, Joffrel C, Larrieu $T$, Madore $C$, et al. Neuroinflammation and aging: influence of dietary $\mathrm{n}-3$ polyunsaturated fatty acid. Lipids and Brain 2011; 18(6): 301-306. http://www.ocl-journal.org/articles/ ocl/pdf/2011/06/ocl2011186p301.pdf

[26] Lim GP, Calon F, Morihara T, Yang F, Teter B, Ubeda O, et al. A diet enriched with the omega-3 fatty acid docosahexaenoic acid reduces amyloid burden in an aged Alzheimer mouse model. J Neurosci 2005; 25(12): 3032-40. http://dx.doi.org/10.1523/JNEUROSCl.4225-04.2005

[27] Hashimoto M, Tanabe Y, Fujii Y, Kikuta T, Shibata H, Shido O. Chronic administration of docosahexaenoic acid ameliorates the impairment of spatial cognition learning ability in amyloid beta-infused rats. J Nutr 2005; 135(3): 54955. http://www.ncbi.nlm.nih.gov/pubmed/15735092

[28] Connor WE, Connor SL. The importance of fish and docosahexaenoic acid in Alzheimer disease. Am J Clin Nutr 2007; 85(4): 929-30. http://www.ncbi.nlm.nih.gov/pubmed/ 17413088

[29] Wu A, Ying Z, Gomez-Pinilla F. Docosahexaenoic acid dietary supplementation enhances the effects of exercise on synaptic plasticity and cognition. Neuroscience 2008; 155: 751-759.

http://dx.doi.org/10.1016/j.neuroscience.2008.05.061

[30] Chytrova G, Ying Z, Gomez-Pinilla F. Exercise contributes to the effects of DHA dietary supplementation by acting on membrane-related synaptic systems. Brain Res 2009; 1341: $32-40$.

http://dx.doi.org/10.1016/j.brainres.2009.05.018

[31] Bousquet M, Gue K, Emond V, Julien P, Kang JX, Cicchetti $\mathrm{F}$, Calon $\mathrm{F}$. Transgenic conversion of omega- 6 into omega-3 fatty acids in a mouse model of Parkinson's disease. J Lipid Res 2011; 52: 263-271. http://dx.doi.org/10.1194/jlr.M011692

[32] Delpech JC, Madore C, Joffre C, Aubert A, Kang JX, Nadjar A, Layé $S$. Transgenic increase in $n-3 / n-6$ fatty acid ratio protects against cognitive deficits induced by an immune challenge through decrease of neuroinflammation. Neuropsychopharmacology 2015; 40(3): 525-36. http://dx.doi.org/10.1038/npp.2014.196

[33] Oh YT, Lee JY, Lee J, Kim H, Yoon KS, Choe W, Kang I. Oleic acid reduces lipopolysaccharide-induced expression of iNOS and COX-2 in BV2 murine microglial cells: possible involvement of reactive oxygen species, p38 MAPK, and IKK/NF-kappaB signaling pathways. Neurosci Lett 2009; 464(2): 93-7. http://dx.doi.org/10.1016/j.neulet.2009.08.040

[34] Alemany R, Navarro MA, Vögler O, Perona JS, Osada J, Ruiz-Gutiérrez $\mathrm{V}$. Olive oils modulate fatty acid content and signaling protein expression in apolipoprotein $E$ knockout mice brain. Lipids 2010; 45(1): 53-61.

http://dx.doi.org/10.1007/s11745-009-3370-y

[35] Berr C, Portet F, Carriere I, Akbaraly TN, Feart C, Gourlet V, et al. Olive oil and cognition: results from the three-city study. Dement Geriatr Cogn Disord 2009; 28(4): 357-64. http://dx.doi.org/10.1159/000253483

[36] Park JS, Woo MS, Kim SY, Kim WK, Kim HS. Repression of interferon-gamma-induced inducible nitric oxide synthase (iNOS) gene expression in microglia by sodium butyrate is mediated through specific inhibition of ERK signaling pathways. J Neuroimmunol 2005; 168: 56-64. http://dx.doi.org/10.1016/i.jneuroim.2005.07.003

[37] Vinolo M, Rodrigues H, Nachbar R, Curi R. Regulation of Inflammation by Short Chain Fatty Acids. Nutrients 2011; 3: 858-876. doi:10.3390/nu3100858. http://www.mdpi.com/ 2072-6643/3/10/858/htm

[38] Huskisson E, Maggini S, Ruf $M$. The influence of micronutrients on cognitive function and performance. J Int Med Res 2007; 35(1): 1-19. http://dx.doi.org/10.1177/147323000703500101

[39] Smith AD, Refsum H. Vitamin B-12 and cognition in the elderly. Am J Clin Nutr 2009; 89(2): 707S-11S. http://dx.doi.org/10.3945/ajcn.2008.26947D

[40] Morris M, Evans D, Bienias J, Tangney C, Hebert L, Scherr P, Schneider J. Dietary Folate and Vitamin B12 Intake and Cognitive Decline Among Community-Dwelling Older Persons Arch Neurol 2005; 62(4): 641-645. http://dx.doi.org/10.1001/archneur.62.4.641

[41] Lokk J. Association of vitamin B12, folate, homocysteine and cognition in the elderly. Scandinavian Journal of Nutrition 2003; 47(3): 132-138. http://dx.doi.org/10.1080/11026480310000662

[42] Whalley LJ, Duthie SJ, Collins AR, Starr JM, Deary IJ, Lemmon $\mathrm{H}$, et al. Homocysteine, antioxidant micronutrients and late onset dementia. Eur J Nutr 2014; 53(1): 277-85. http://dx.doi.org/10.1007/s00394-013-0526-6

[43] Harrison F. A critical review of Vitamin C for the prevention of age-related cognitive decline and Alzheimer's disease. J Alzheimers Dis 2012; 29(4): 711-26. doi: 10.3233/JAD-2012111853. http://www.ncbi.nlm.nih.gov/pubmed/22366772

[44] Mecocci P, Polidori MC. Antioxidant clinical trials in mild cognitive impairment and Alzheimer's disease. Biochim Biophys Acta 2012; 1822(5): 631-8. http://dx.doi.org/10.1016/j.bbadis.2011.10.006

[45] Miller JW. Vitamin D and cognitive function in older adults: are we concerned about vitamin D-mentia? Neurology 2010; 74(1): 13-5.

http://dx.doi.org/10.1212/WNL.0b013e3181c719a2

[46] Balion C, Griffith LE, Strifler L, Henderson M, Patterson C, Heckman G, Llewellyn DJ, Raina. Vitamin D, cognition, and dementia: a systematic review and meta-analysis PNeurology 2012; 79(13): 1397-405.

\section{http://dx.doi.org/10.1212/WNL.0b013e31826c197f}

[47] Falkingham M, Abdelhamid A, Curtis P, Fairweather-Tait S Dye $L$, Hooper $L$. The effects of oral iron supplementation on cognition in older children and adults: a systematic review and meta-analysis. Nutr J 2010; 9: 4 http://dx.doi.org/10.1186/1475-2891-9-4

[48] McNeill G, Avenell A, Campbell MK, Cook JA, Hannaford PC Kilonzo MM, et al. Effect of multivitamin and multimineral supplementation on cognitive function in men and women aged 65 years and over: a randomised controlled trial. Nutr $\mathrm{J}$ 2007; 6: 10 .

http://dx.doi.org/10.1186/1475-2891-6-10

[49] Kovacsova M, Barta A, Parohova J, Vrankova S, Pechanova O. Neuroprotective Mechanisms of Natural Polyphenolic Compounds. Act Nerv Super Rediviva 2010; 52(3): 181-186. http://www.rediviva.sav.sk/52i3/181.pdf 
[50] Campos-Esparza MR, Sánchez-Gómez MV, Matute C. Molecular mechanisms of neuroprotection by two natural antioxidant polyphenols. Cell Calcium 2009; 45(4): 358-68. http://dx.doi.org/10.1016/j.ceca.2008.12.007

[51] Capiralla H, Vingtdeux V, Zhao H, Sankowski R, Al-Abed $Y$, Davies $P$, Marambaud $P$. Resveratrol mitigates lipopolysaccharide- and $A \beta$-mediated microglial inflammation by inhibiting the TLR4/NF-KB/STAT signaling cascade. J Neurochem 2012; 120(3): 461-72.

http://dx.doi.org/10.1111/j.1471-4159.2011.07594.x

[52] Lamporta D, Dyeb L, Wightmanc J, Lawtonb C. The effects of flavonoid and other polyphenol consumption on cognitive performance: A systematic research review of human experimental and epidemiological studies. Nutrition and Aging 2012; 1: 5-25. http://iospress.metapress.com/content/ c813pm8470014458/

[53] Lau FC, Bielinski DF, Joseph JA. Inhibitory effects of blueberry extract on the production of inflammatory mediators in lipopolysaccharide-activated BV2 microglia. J Neurosci Res 2007; 85: 1010-1017.

http://dx.doi.org/10.1002/jnr.21205

[54] Shukitt-Hale B, Lau FC, Carey AN, Galli RL, Spangler EL, Ingram DK, Joseph JA. Blueberry polyphenols attenuate kainic acid-induced decrements in cognition and alter inflammatory gene expression in rat hippocampus. Nutritional Neuroscience 2008; 11(4): 172-182. http://dx.doi.org/10.1179/147683008X301487

[55] Lau FC, Bielinski DF, Joseph JA. Inhibitory effect of blueberry extract on the production of inflammatory mediators in Ips-activated bv2 microglia. Age 2006; 28(1): 46. http://www.ncbi.nlm.nih.gov/pubmed/17265471

[56] Laua F, Josepha J, McDonald J, Kaltb W. Attenuation of iNOS and COX2 by blueberry polyphenols is mediated through the suppression of NF-jB activation. J Funct Foods 2009; 274-283. http://dx.doi.org/10.1016/j.jff.2009.05.001

[57] Joseph JA, Shukitt-Hale B, Willis LM. Grape juice, berries, and walnuts affect brain aging and behavior. J Nutr 2009; 139(9): 1813S-7S.

http://dx.doi.org/10.3945/jn.109.108266

[58] Willis LM, Shukitt-Hale B, Joseph JA. Recent advances in berry supplementation and age-related cognitive decline. Curr Opin Clin Nutr Metab Care 2009; 12(1): 91-4. http://dx.doi.org/10.1097/MCO.0b013e32831b9c6e

[59] Jang S, Kelley KW, Johnson RW. Luteolin reduces IL-6 production in microglia by inhibiting JNK phosphorylation and activation of AP-1. Proc Natl Acad Sci USA 2008; 105(21): 7534-9.

http://dx.doi.org/10.1073/pnas.0802865105

[60] Spencer J. The impact of fruit flavonoids on memory and cognition. Br J Nutr 2010; 104(Suppl 3): S40-7.

http://dx.doi.org/10.1017/S0007114510003934

[61] Willis LM, Shukitt-Hale B, Joseph JA. Modulation of cognition and behavior in aged animals: role for antioxidant- and essential fatty acid-rich plant foods. Am J Clin Nutr 2009; 89(5): 1602S-1606S.

http://dx.doi.org/10.3945/ajcn.2009.26736J

[62] Nehlig A. The neuroprotective effects of cocoa flavanol and its influence on cognitive performance. $\mathrm{Br} \mathrm{J}$ Clin Pharmacol 2013; 75(3): 716-27. doi: 10.1111/j.1365-2125.2012.04378.x http://www.ncbi.nlm.nih.gov/pubmed/22775434

[63] Williams RJ, Spencer JP. Flavonoids, cognition, and dementia: actions, mechanisms, and potential therapeutic utility for Alzheimer disease. Free Radic Biol Med 2012; 52(1): 35-45.

http://dx.doi.org/10.1016/j.freeradbiomed.2011.09.010

[64] Nurk E, Refsum H, Drevon CA, Tell GS, Nygaard HA, Engedal K, Smith AD. Intake of flavonoid-rich wine, tea, and chocolate by elderly men and women is associated with better cognitive test performance. J Nutr 2009; 139(1): 120-7. http://dx.doi.org/10.3945/jn.108.095182

[65] Scholey AB, French SJ, Morris PJ, Kennedy DO, Milne AL, Haskell CF. Consumption of cocoa flavanols results in acute improvements in mood and cognitive performance during sustained mental effort. J Psychopharmacol 2010; 24(10): 1505-14. http://dx.doi.org/10.1177/0269881109106923

[66] Ho SC, Kuo CT. Hesperidin, nobiletin, and tangeretin are collectively responsible for the anti-neuroinflammatory capacity of tangerine peel (Citri reticulatae pericarpium). Food Chem Toxicol 2014; 71: 176-82. http://dx.doi.org/10.1016/j.fct.2014.06.014

[67] Shu Z, Yang B, Zhao H, Xu B, Jiao W, Wang Q, Wang Z, Kuang $H$. Tangeretin exerts anti-neuroinflammatory effects via NF-kB modulation in lipopolysaccharide-stimulated microglial cells. Int Immunopharmacol 2014; 19(2): 275-82. http://dx.doi.org/10.1016/j.intimp.2014.01.011

[68] Xu PX, Wang SW, Yu XL, Su YJ, Wang T, Zhou W, et al. Rutin improves spatial memory in Alzheimer's disease transgenic mice by reducing $A \beta$ oligomer level and attenuating oxidative stress and neuroinflammation. Behav Brain Res 2014; 264: 173-80. http://dx.doi.org/10.1016/j.bbr.2014.02.002

[69] Park JS, Park EM, Kim DH, Jung K, Jung JS, Lee EJ, et al. Anti-inflammatory mechanism of ginseng saponins in activated microglia. J Neuroimmunol 2009; 209(1-2): 40-9. http://dx.doi.org/10.1016/i.jneuroim.2009.01.020

[70] Barone E, Calabrese V, Mancuso C. Ferulic acid and its therapeutic potential as a hormetin for age-related diseases. Biogerontology 2009; 10(2): 97-108. http://dx.doi.org/10.1007/s10522-008-9160-8

[71] Begum AN, Jones MR, Lim GP, Morihara T, Kim P, Heath $\mathrm{DD}$, et al. Curcumin structure-function, bioavailability, and efficacy in models of neuroinflammation and Alzheimer's disease. J Pharmacol Exp Ther 2008; 326(1): 196-208. http://dx.doi.org/10.1124/jpet.108.137455

[72] Park SY, Jin ML, Kim YH, Kim Y, Lee SJ. Anti-inflammatory effects of aromatic-turmerone through blocking of NF-KB, $\mathrm{JNK}$, and p38 MAPK signaling pathways in amyloid $\beta$ stimulated microglia. Int Immunopharmacol 2012; 14(1): 1320.

\section{http://dx.doi.org/10.1016/j.intimp.2012.06.003}

[73] Ho S, Chang K, Chang P. Inhibition of neuroinflammation by cinnamon and its main components. Food Chem 2013; 138: 2275-2282.

http://dx.doi.org/10.1016/j.foodchem.2012.12.020

[74] Kim M, Koppula S, Jung S, Kim J, Lee H, Park Y, Lee K, Park T. Kang Olea europaea Linn (Oleaceae) Fruit Pulp Extract Exhibits Potent Antioxidant Activity and Attenuates Neuroinflammatory Responses in LipopolysaccharideStimulated Microglial Cells Tropical. J Pharmaceut Res 2013; 12 (3): 357-362. http://www.tjpr.org/vol12_no3/2013_12_3_ 13.php

[75] Crea R, Bilter C, Nolin L, Pontoniere P. Anti-inflammatory activity of hydroxytyrosol - Inhibition of cytokine production in a parkinson's model system of neuroinflammation. Agro Food Industry $\mathrm{Hi}$ Tech 2012; 23(2): 26-29. http://www. teknoscienze.com/articles/agro-food-industry-hi-tech

[76] Bournival J, Plouffe M, Renaud J, Provencher C, Martinoli MG. Quercetin and sesamin protect dopaminergic cells from MPP+-induced neuroinflammation in a microglial (N9)neuronal (PC12) coculture system. Oxid Med Cell Longev. 2012; 2012: 921941. doi: 10.1155/2012/921941. Epub 2012 Jul 3. http://www.ncbi.nlm.nih.gov/pubmed/22919443

[77] Moon M, Kim H, Choi J, Oh H, Lee P, Ha S, et al. 6-Shogaol, an active constituent of ginger, attenuates neuroinflammation 
and cognitive deficits in animal models of dementia. Biochem Biophys Res Commun 2014; 449(1): 8-13.

http://dx.doi.org/10.1016/..bbrc.2014.04.121

[78] Ha SK, Moon E, Kim SY. Chrysin suppresses LPS-stimulated proinflammatory responses by blocking NF-KB and JNK activations in microglia cells. Neurosci Lett 2010; 485(3): 143-7.

http://dx.doi.org/10.1016/j.neulet.2010.08.064

[79] Dirscherl K, Karlstetter M, Ebert S, Kraus D, Hlawatsch J, Walczak $\mathrm{Y}$, et al. Luteolin triggers global changes in the microglial transcriptome leading to a unique antiinflammatory and neuroprotective phenotype. J Neuroinflammation 2010; $7: 3$.

http://dx.doi.org/10.1186/1742-2094-7-3

[80] Zhu LH, Bi W, Qi RB, Wang HD, Lu DX. Luteolin inhibits microglial inflammation and improves neuron survival against inflammation. Int J Neurosci 2011; 121(6): 329-36. http://dx.doi.org/10.3109/00207454.2011.569040

[81] Abraham J, Johnson RW. Consuming a diet supplemented with resveratrol reduced infection-related neuroinflammation and deficits in working memory in aged mice. Rejuvenation Res 2009; 12(6): 445-53. http://dx.doi.org/10.1089/rej.2009.0888

[82] Bureau G, Longpré F, Martinoli MG. Resveratrol and quercetin, two natural polyphenols, reduce apoptotic neuronal cell death induced by neuroinflammation. J Neurosci Res 2008; 86(2): 403-10. http://dx.doi.org/10.1002/jnr.21503

[83] Chinta SJ, Ganesan A, Reis-Rodrigues P, Lithgow GJ, Andersen JK. Anti-inflammatory role of the isoflavone diadzein in lipopolysaccharide-stimulated microglia: implications for Parkinson's disease. Neurotox Res 2013; 23(2): 145-53. http://dx.doi.org/10.1007/s12640-012-9328-5

[84] Ahmad A, Ramasamy K, Jaafar S, Majeed A, Mani V. Total isoflavones from soybean and tempeh reversed scopolamine-induced amnesia, improved cholinergic activities and reduced neuroinflammation in brain. Food Chem Toxicol 2014; 65: 120-8.

http://dx.doi.org/10.1016/j.fct.2013.12.025

[85] Haque A, Hashimoto M, Katakura M, Tanabe $Y$, Hara $Y$, Shido $O$. Long-term administration of green tea catechins improves spatial cognition learning ability in rats. J Nutr 2006; 136(4): 1043-7. http://www.ncbi.nlm.nih.gov/pubmed/ 16549472

[86] Anandhan A, Essa M, Manivasagam T. Therapeutic attenuation of neuroinflammation and apoptosis by black tea theaflavin in chronic MPTP/probenecid model of Parkinson's disease. Neurotox Res 2013; 23(2): 166-73. http://dx.doi.org/10.1007/s12640-012-9332-9
[87] Cartford M, Gemma C, Bickford PC. Eighteen-month-old Fischer 344 rats fed a spinach-enriched diet show improved delay classical eyeblink conditioning and reduced expression of tumor necrosis factor alpha (TNFalpha) and TNFbeta in the cerebellum. J Neurosci 2002; 22(14): 5813-6. http://www.ncbi.nlm.nih.gov/pubmed/12122042

[88] Nerurkar P, Johns L, Nuesa L, Kipyakwai G, Volper E, Sato $\mathrm{R}$, et al. Momordica charantia (bitter melon) attenuates highfat diet-associated oxidative stress and neuroinflammation. $J$ Neuroinflammation 2011; 8: 64. http://dx.doi.org/10.1186/1742-2094-8-64

[89] Moon M, Choi J, Kim S, Oh M. Bombycis excrementum reduces amyloid- $\beta$ oligomer-induced memory impairments, neurodegeneration, and neuroinflammation in mice. $J$ Alzheimers Dis 2014; 41(2): 599-613. http://www.ncbi.nlm. nih.gov/pubmed/24898636

[90] Brahmachari S, Jana A, Pahan K. Sodium benzoate, a metabolite of cinnamon and a food additive, reduces microglial and astroglial inflammatory responses. J Immunol 2009; 183(9): 5917-27.

\section{http://dx.doi.org/10.4049/jimmunol.0803336}

[91] Chen J, Liu K, Yang T, Hwang J, Chan Y, Lee I. Spirulina and $\mathrm{C}$-phycocyanin reduce cytotoxicity and inflammationrelated genes expression of microglial cells. Nutr Neurosci 2012.

http://dx.doi.org/10.1179/1476830512Y.0000000020

[92] Willis L, Bielinski D, Fisher D, Matthan N, Joseph J. Walnut extract inhibits LPS-induced activation of BV-2 microglia via internalization of TLR4: possible involvement of phospholipase D2. Inflammation 2010; 33(5): 325-33. doi: 10.1007/s10753-010-9189-0. http://www.ncbi.nlm.nih.gov/ pubmed/20213499

[93] Colín-González A, Ortiz-Plata A, Villeda-Hernández J, Barrera D, Molina-Jijón E, Pedraza-Chaverrí J, Maldonado P. Aged garlic extract attenuates cerebral damage and cyclooxygenase-2 induction after ischemia and reperfusion in rats. Plant Foods Hum Nutr 2011; 66(4): 348-54. http://dx.doi.org/10.1007/s11130-011-0251-3

[94] Townsend B, Chen Y, Jeffery E, Johnson R. Dietary broccoli mildly improves neuroinflammation in aged mice but does not reduce lipopolysaccharide-induced sickness behavior. Nutr Res 2014; 34(11): 990-9. http://dx.doi.org/10.1016/j. nutres.2014.10.001

[95] Giles G, Mahoney C, Brunyé T, Gardony A, Taylor H, Kanarek R. Differential cognitive effects of energy drink ingredients: caffeine, taurine, and glucose. Pharmacol Biochem Behav 2012; 102(4): 569-77. http://dx.doi.org/10.1016/j.pbb.2012.07.004 